\title{
High Anaplastic Lymphoma Kinase Immunohistochemical Staining in Neuroblastoma and Ganglioneuroblastoma Is an Independent Predictor of Poor Outcome
}

Floor A.M. Duijkers, ${ }^{*}$ José Gaal, ${ }^{\dagger}$ Jules P.P. Meijerink, ${ }^{\star}$ Pieter Admiraal, ${ }^{*}$ Rob Pieters, ${ }^{*}$ Ronald R. de Krijger, ${ }^{\dagger}$ and Max M. van Noesel*

From the Department of Pediatric Oncology-Hematology," Sophia Children's Hospital, and the Department of Pathology, ${ }^{\dagger}$ University Medical Center, Erasmus MC, Rotterdam, the Netherlands

Anaplastic lymphoma kinase (ALK) mutations occur in $3 \%$ to $11 \%$ of neuroblastoma (NBL) cases and are associated with high ALK levels. However, high ALK levels appear to be a mutation-independent hallmark of NBL. Evidence about the prognostic relevance of $A L K$ mutations and ALK tumor positivity in patients with NBL has been inconclusive. In this study, we investigated the prognostic relevance of ALK positivity by IHC and $A L K$ mutation status by PCR sequencing in 71 NBL, 12 ganglioneuroblastoma (GNBL), and 20 ganglioneuroma samples in a multivariate model. $A L K$ mutations were present in 2 of 72 NBL and 2 of 12 GNBL samples, which all contained many ALK-positive cells ( $>50 \%)$. In addition, half of all NBL samples showed ALK positivity in most ( $>50 \%$ ) of tumor cells, whereas half of the GNBL showed staining in $<20 \%$ of the tumor cells. In most ganglioneuroma samples, a low percentage of tumor cells stained positive for ALK, which mainly involved ganglion cells. Higher percentages of ALK-positive cells in NBL and GNBL patient samples correlated with inferior survival in univariate and multivariate analyses with established prognostic factors, such as stage, age, and MYCN status. In conclusion, ALK positivity by IHC is an independent, poor prognostic factor in patients with GNBL and NBL. ALK IHC is an easy test suitable for future risk stratification in patients with NBL and GNBL. (Am J Pathol 2012, 180:1223-1231; DOI: 10.1016/j.ajpath.2011.12.003)
Neuroblastomas (NBLs) are pediatric tumors that arise from the neural crest. These tumors are often aneuploid and possess highly recurrent copy number changes, including gain of $17 q$ and loss of heterozygosity of $1 p, 11 q$, and $14 \mathrm{q} .{ }^{1-4}$ However, few recurrent gene mutations have been discovered thus far. The most common recurrent mutations are found in MYCN (amplified in 20\% to 25\%), ${ }^{5}$ CCND2 (amplified in 2.4\%), ${ }^{6}$ and the more recently discovered anaplastic lymphoma kinase $(A L K)$ gene. ${ }^{7-12}$ Many familial or syndromatic NBL diseases are explained by $A L K$ or PHOX2B mutations. ${ }^{10,11}$

$A L K$ mutations are the second most common genetic mutation in NBL, with point mutations in $3 \%$ to $11 \%$ and amplifications in $1 \%$ to $4 \%$ of the patients. ${ }^{7-12}$ Mutations of the $A L K$ gene have also been described as the most common cause of hereditary NBL. ${ }^{10,11}$ The point mutations in NBL are located in the tyrosine kinase domain of ALK and activate kinase activity, ${ }^{8,10,13}$ resulting in phosphorylation of downstream targets. ${ }^{8-10,14,15}$ Mutant ALK acts as a bona fide oncogene because $\mathrm{NIH} 3 \mathrm{~T} 3$ transfectants that express mutant ALK F1174L or K1062M molecules enforce malignant engraftment in mice. ${ }^{8}$

The normal function of the ALK protein is not yet fully elucidated, but ALK is especially expressed during the early differentiation of neuronal tissues. ${ }^{16-20}$ High levels of ALK have been measured in fetal neuroblasts. ${ }^{16,21}$ Many NBLs show ALK positivity by immunohistochemistry $(I H C)$, although a wide range of positivity levels in NBL patient cohorts has been described. ${ }^{13,21-24}$ The relevance of high ALK expression for the pathogenesis of this disease is unclear. The expression of ALK in the more

Supported by Dutch Neuroblastoma Foundation Villa Joep, ODAS Foundation (Delft, the Netherlands), and a grant from The Dutch Cancer Society (2005-3452).

Accepted for publication December 2, 2011.

Supplemental material for this article can be found at http://ajp. amjpathol.org or at doi: 10.1016/j.ajpath.2011.12.003.

Address reprint requests to Max M. van Noesel, M.D., Ph.D., Erasmus MC-Sophia Children's Hospital, Dr Molewaterplein 60, 3015 GJ Rotterdam, the Netherlands. E-mail: m.vannoesel@erasmusmc.nl. 
Table 1. Summary of Literature on ALK and Prognosis

\begin{tabular}{|c|c|c|c|c|}
\hline Reference & $\begin{array}{c}\text { Type of } A L K \\
\text { aberration studied }\end{array}$ & $\begin{array}{l}\text { NBL Patients with an } \\
\text { aberration } \\
{[\text { no./total }(\%)]}\end{array}$ & Univariate analysis & Multivariate analysis \\
\hline \multirow[t]{3}{*}{7} & ALK point mutation & $10 / 90(11.1)$ & $\begin{array}{l}33 \% \text { OS compared with } \\
\text { non-ALK aberrated }\end{array}$ & NA \\
\hline & ALK amplification & $4 / 108(3.7)$ & $\begin{array}{l}50 \% \text { OS compared with } \\
\text { non-ALK aberrated }\end{array}$ & NA \\
\hline & ALK gain & 20/108 (18.5) & $\begin{array}{l}52 \% \text { OS compared with } \\
\text { non-ALK aberrated }\end{array}$ & NA \\
\hline 8 & $\begin{array}{l}\text { ALK point mutation or } \\
\text { amplification }\end{array}$ & $\begin{array}{r}13 / 215(6.0) \\
6 / 215(2.8)\end{array}$ & NA & $\begin{array}{l}\text { NS }(P=0.58) \text { in model. including } \\
\text { MYCN status and stage } 4\end{array}$ \\
\hline 11 & $\begin{array}{l}\text { ALK gain or } \\
\text { amplification }\end{array}$ & $\begin{array}{l}112 / 491(22.8) \\
16 / 491(3.3)\end{array}$ & $\begin{array}{l}\text { Significantly correlated with } \\
\text { death from disease }\end{array}$ & NA \\
\hline 13 & $\begin{array}{l}\text { Low ALK IHC staining } \\
\text { ( }<10 \% \text { of the cells) } \\
\text { High ALK IHC staining } \\
\text { ( }>50 \% \text { of the cells) }\end{array}$ & $\begin{array}{l}24 / 82(29.3) \\
45 / 82(54.9)\end{array}$ & $\begin{array}{l}\text { High ALK IHC is significantly } \\
\text { associated with inferior } \\
\text { EFS }\end{array}$ & NA \\
\hline 22 & $\begin{array}{l}\text { Low ALK IHC staining } \\
\quad(<50 \% \text { of the cells) } \\
\text { High ALK IHC staining } \\
\text { ( } \geq 50 \% \text { of the cells })\end{array}$ & $\begin{array}{l}17 / 54(31.5) \\
37 / 54(68.5)\end{array}$ & $\begin{array}{l}\text { High ALK IHC is significantly } \\
\text { associated with higher } \\
\text { DOD and inferior PFS }\end{array}$ & NA \\
\hline 22 & $\begin{array}{l}\text { ALK mRNA (higher or } \\
\text { lower than median), } \\
\text { three cohorts }\end{array}$ & $\begin{array}{l}\text { 126/251 (50.2) high } \\
\text { ALK }\end{array}$ & $\begin{array}{l}\text { High ALK is significantly } \\
\text { associated with more DOD } \\
\text { and lower PFS }\end{array}$ & $\begin{array}{l}\text { High } A L K \text { expression is significantly } \\
\text { correlated with inferior survival } \\
(P=0.01) \text { in model, including } \\
\text { MYCN status, age, and stage }\end{array}$ \\
\hline & & $\begin{array}{l}\text { 51/101 (50.5) high } \\
\quad \text { ALK }\end{array}$ & $\begin{array}{l}\text { High ALK is significantly } \\
\text { associated with more DOD } \\
\text { and lower PFS }\end{array}$ & $\begin{array}{l}\text { NS, model including MYCN status, } \\
\text { age, and stage }\end{array}$ \\
\hline & & 44/88 (50) high ALK & $\begin{array}{l}\text { High ALK is significantly } \\
\text { associated with more DOD } \\
\text { and lower PFS }\end{array}$ & $\begin{array}{l}\text { NS, model including MYCN status, } \\
\text { age, and stage }\end{array}$ \\
\hline 22 & $\begin{array}{l}\text { ALK point mutation or } \\
\text { amplification }\end{array}$ & $57 / 635(9.0)$ & NS & NA \\
\hline 22 & F1174 ALK mutation & $15 / 593(2.5)$ & $\begin{array}{l}\text { Significantly more DOD in } \\
\text { F1174 mutated versus WTs }\end{array}$ & NA \\
\hline 22 & Type of ALK mutation & $\begin{array}{l}\text { 23/38 (60.5) R1275Q } \\
15 / 38(39.5) \mathrm{F} 1174\end{array}$ & $\begin{array}{l}\text { Significantly more DOD in } \\
\text { F1174 mutated versus } \\
\text { R1275Q mutated }\end{array}$ & NA \\
\hline 25 & ALK point mutation & $21 / 261(8.0)$ & $\begin{array}{l}\text { Significantly correlated with } \\
\text { inferior OS and EFS }\end{array}$ & $\begin{array}{l}\text { NS, model including ALK mRNA } \\
\text { expression and NS, model } \\
\text { including ALK mRNA expression, } \\
\text { stage, age, MYCN, and LOH1p }\end{array}$ \\
\hline 25 & $\begin{array}{l}\text { ALK mRNA expression } \\
\text { as continuous } \\
\text { variable ( } 2 \text { log ratio } \\
\text { array) }\end{array}$ & 261 & $\begin{array}{l}\text { Increasing ALK levels are } \\
\text { significantly associated } \\
\text { with decreasing OS and } \\
\text { EFS }\end{array}$ & $\begin{array}{l}\text { Increasing ALK levels are } \\
\text { significantly associated with } \\
\text { decreasing OS and EFS }(P< \\
\text { 0.001; HR OS, 8.70; HR EFS, } \\
\text { 4.26) in model, including ALK } \\
\text { mutation status; NS in model, } \\
\text { including ALK mutation status, } \\
\text { stage, age, MYCN, and LOH1p }\end{array}$ \\
\hline
\end{tabular}

This table summarizes current literature about ALK as a prognostic factor in NBL. This includes the role of ALK point mutations, gains, and amplifications and ALK expression in NBL patient survival.

DOD, death of disease; EFS, event-free survival; HR, hazard ratio; LOH, loss off heterozygosity; NA, not available; NS, not significant; OS, overall survival; PFS, progression-free survival.

benign ganglioneuroblastoma (GNBL) and ganglioneuroma (GN) has not been investigated yet and is included in this study.

ALK aberrations and high ALK expression have been linked to NBL patient prognosis. Results from these studies are reviewed in Table 1.7,8,11,13,22,25 ALK point mutations and copy number gains are associated with high ALK levels and with inferior prognosis of patients with NBL in univariate analyses. ${ }^{7-9,11,26,27}$ However, ALK mu- tation status has not been identified as an independent prognostic factor in multivariate analyses. ${ }^{8,22,25}$ Two studies $^{22,25}$ showed a correlation between ALK mRNA levels in NBL samples and inferior survival univariately, whereas in multivariate analysis, only one of four cohorts remained significant. ${ }^{22}$ High percentages of ALK-positive cells by $\mathrm{IHC}$ were correlated with inferior survival in $2009,{ }^{13}$ which was confirmed by others. ${ }^{22}$ Because ALK $\mathrm{IHC}$ is an easily applicable technique for routine diagnos- 
Table 2. Patient Characteristics

\begin{tabular}{|c|c|c|c|c|}
\hline Characteristics & Ganglioneuroma & Ganglioneuroblastoma & Neuroblastoma & $P$ value \\
\hline Patients [no. (\%)] & $20(19)$ & $12(12)$ & $71(69)$ & \\
\hline Median age (years) & 7.5 & 3.3 & 2.7 & $<0.001^{*}$ \\
\hline Male/female ratio & 0.5 & 0.5 & 0.6 & $0.817^{\dagger}$ \\
\hline INSS stage [no. (\%)] & NA & & & \\
\hline | & & $1(8)$ & $9(13)$ & $1.000^{\ddagger}$ \\
\hline II & & $3(25)$ & $7(10)$ & $0.154^{\ddagger}$ \\
\hline III & & $3(25)$ & $12(17)$ & $0.447^{\ddagger}$ \\
\hline IV & & $4(33)$ & $41(58)$ & $0.132^{\ddagger}$ \\
\hline IVs & & $1(8)$ & $2(3)$ & $0.378^{\ddagger}$ \\
\hline MYCN status present/tested & NA & $0 / 9$ & $8 / 54$ & $0.588^{\ddagger}$ \\
\hline Risk group (COG): risk stratification possible [no. (\%)] & NA & 12 & $67^{\star \star}$ & \\
\hline Low & & $5(42)$ & $16(24)$ & $0.285^{\ddagger}$ \\
\hline Medium & & $2(17)$ & $14(21)$ & $1.000^{\ddagger}$ \\
\hline High & & $5(42)$ & $37(55)$ & $0.386^{\ddagger}$ \\
\hline
\end{tabular}

Differences in basic characteristics between the groups of patients were tested. INSS staging is mainly based on tumor resectability, lymph node involvement, and distant metastasis. COG risk group stratification is based on MYCN, age, INSS stage, histological features, and ploidy. Significant $P$ values $(P<0.05)$ are boldfaced.

${ }^{*}$ Kruskal-Wallis test.

${ }^{+} \chi^{2}$ test.

\#Fisher's exact test.

${ }^{* *}$ No risk stratification possible for four patients due to missing data.

NA, not applicable; IVs, special stage of NBL disease in infants with minimal bone-marrow invasion and favorable prognosis.

tics, this method could also be applied for routine patient risk stratification, particularly in NBL patient trials with ALK inhibitors. Multivariate analysis of ALK protein expression in NBL has not been performed yet.

We, therefore, studied ALK protein expression by IHC in NBL, GNBL, and GN patient samples, which was compared with $A L K$ mutation status and prognosis.

\section{Materials and Methods}

\section{Patient Samples}

A total of 103 formalin-fixed, paraffin-embedded (FFPE) tumor samples of pediatric patients with NBL, GNBL, and GN, diagnosed as having the condition between 1987 and 2010, were identified in the database of the Erasmus MC Department of Pathology. The patient characteristics are described in Table 2. Informed consent was obtained from all patients or parents to use leftover diagnostic material for research purposes, according to the Declaration of Helsinki. This study was approved by the Institutional Review Board of the Erasmus MC, Rotterdam, the Netherlands.

\section{DNA Isolation}

DNA was isolated from FFPE material comprising a minimum of $70 \%$ tumor cells (93 of the 103 patients). For most patient samples, DNA was isolated using the DNA isolation minikit (Qiagen, Venlo, the Netherlands). For some paraffin samples containing only small amounts of tissue, DNA isolation was specifically performed without precipitation steps. For these last samples, direct lysis involved overnight incubation of paraffin material at $57^{\circ} \mathrm{C}$ in $180 \mu \mathrm{L}$ of lysis buffer (Molecular Diagnostics, Pathology Erasmus MC-University Medical Center, Rotterdam, the Netherlands) with $20 \mu \mathrm{L}$ of Proteinase $\mathrm{K}(10 \mathrm{mg} / \mathrm{mL})$. Proteinase $\mathrm{K}$ was subsequently inactivated for 5 minutes at $95^{\circ} \mathrm{C}$. RNase was added for 1 hour at $37^{\circ} \mathrm{C}$ for purification of the DNA. Material was stored at $4^{\circ} \mathrm{C}$ after centrifuging for 1 minute at $17,000 \times g$ for separation of paraffin and DNA.

\section{IHC Data}

The $\alpha$-ALK/p80 monoclonal antibody (RM-9108; Thermo Fisher Scientific Inc./NeoMarker, Fremont, CA) was used for this study. Two antibodies against phosphorylated ALK protein Y1604 [3341 (Cell Signaling, Beverly, MA) and 1891-1 (Epitomics, Burlingame, CA)] were tested. The antibodies were applied on FFPE tissue sections of the tumors. An ALK-translocated $t(2 ; 5)$ anaplastic largecell lymphoma sample was used as a positive control. Normal lymph node tissue was used as a negative control. From the FFPE material, sections (4 to $5 \mu \mathrm{m}$ thick) were cut and mounted on glass slides. The sections were deparaffinized and rehydrated, and heat-induced epitope retrieval was performed by heating in Tris-EDTA buffer, $\mathrm{pH}$ 9.0, at $100^{\circ} \mathrm{C}$ for 15 minutes. The slides were then rinsed in tap water, followed by incubation in 3\% $\mathrm{H}_{2} \mathrm{O}_{2}$ in PBS for 30 minutes.

The antibodies were diluted in normal antibody diluent (100 $\mu \mathrm{L}$ per slide; Klinipath, Duiven, the Netherlands), and slides were incubated with $\alpha$-phophorylated ALK (pALK) $(1: 100$ to $1: 2000)$ or with $\alpha$-ALK $(1: 50)$ at $4^{\circ} \mathrm{C}$ overnight. Washing was performed with Tris-Tween $0.5 \%, \mathrm{pH}$ 8.0. Dako ChemMate envision horseradish peroxidase was applied for 30 minutes (100 $\mu \mathrm{L}$ per slide; Dako envision kit; Dako, Glostrup, Denmark), followed by rinsing with PBS. Diaminobenzidine tetrahydrochloride (100 $\mu \mathrm{L}$ per slide; Dako envision kit) was applied twice, for 4 minutes each time, after which the slides were rinsed with distilled water. Slides were counterstained with Harris hematoxylin for 1 minute, rinsed with tap water, and covered with coverslips. 
Three tumor samples were used to validate antibody specificity after antigen retrieval in FFPE material by costaining of frozen tissue material. Frozen tissue material was fixed in $4 \%$ fresh paraformaldehyde; staining was similar to that previously mentioned for FFPE material.

International Neuroblastoma Pathology Committee classification was blindly scored on H\&E-stained FFPE samples by one of the authors (R.R.d.K.). ${ }^{28,29}$

\section{Quantification of ALK Staining}

The percentage of ALK-positive staining cells of the tumor (neuroblasts and ganglion cells) was primarily scored by one of the authors (F.D.) and independently and blindly scored by an experienced pathologist (R.R.d.K.). ALK positivity was estimated per viewing field, and viewing fields were averaged for the whole tumor on a single slide. Cytoplasmic and membranous staining findings were both considered positive. The percentage of ALK-positive tumor cells was categorized as follows: category $1,<20 \%$ ALK-positive cells; category $2,20 \%$ to $50 \%$ ALK-positive cells; category 3, 50\% to $75 \%$ ALKpositive cells; and category $4,75 \%$ to $100 \%$ ALK-positive cells. The interobserver correlation was $84.5 \%$. Reported ALK categories are those scored by one of the authors (R.R.d.K.).

\section{Determination of MYCN Amplification Status and Loss of Heterozygosity $1 p$}

From 1994 onward, MYCN amplification status and loss of heterozygosity of $1 p$ were prospectively determined in $N B L$ and healthy patient lymphocytes by using Southern blot analysis in the Dutch Neuroblastoma reference lab (Academic Medical Center, Amsterdam, the Netherlands). ${ }^{30}$ For some patients diagnosed as having the condition before 1994, we determined the MYCN amplification status by multiple ligand-dependent probe amplification. The NBL Salsa 251-B mix of MRC Holland (Amsterdam) was used with standard multiple liganddependent probe amplification conditions, and fragment separation was performed on an ABI3100 system (Applied Biosystems, Foster City, CA). DNA isolated from normal kidney FFPE material was used as a normal control. Data analysis was performed with Genemarker software (SoftGenetics LLC, State College, PA) using internal control probe normalization. Multiple ligand-dependent probe amplification analysis was performed and amplification was defined as five gene copies or more (ratio of sample/normal control, 1; amplification, $\geq 2.5$ ), whereas a smaller increase in copy number was defined as a chromosomal gain. Copy number gains that exceed $>20$ copies (only observed for MYCN) were not quantifiable, and these were considered as having an amplification.

\section{Sequencing}

PCR primers for the genomic region, corresponding to ALK exons 20, 22, 23, 24, and 25, including PCR and sequencing conditions, were previously described. ${ }^{31}$

\section{Statistics}

Statistical analyses were performed with SPSS 15.0 (IBM, New York, NY). A log-rank test for trend was used for univariate analysis of ALK expression and survival, and a Cox proportional hazard model was used for multivariate analysis. Differences between groups were determined by a Kruskal-Wallis test for continuous variables and a $\chi^{2}$ test or a Fisher's exact test for categorical variables. Trend tests were performed by a $\chi^{2}$ test for trend in the case of an ordinal variable and a categorical variable, Spearman's rank correlation coefficient in the case of two ordinal variables, and a Jonckheere-Terpstra test if the variables were ordinal versus continuous. Kaplan-Meier curves and bar plots were generated using GraphPad Prism, version 4 (GraphPad Software, Inc., La Jolla, CA).

\section{Results}

\section{Characterization of Patients}

We analyzed a panel of 103 pediatric patient samples comprising 71 NBLs, 12 GNBLs, and 20 GNs. Patient characteristics are summarized in Table 2. The tumor distribution of these patient samples over International Neuroblastoma Staging System (INSS) or Children's Oncology Group (COG) classification categories is as expected and did not differ between patients with GNBL and NBL. ${ }^{32,33}$ Patients with GNBL and NBL were younger than patients with GN $(P<0.001)$, as expected. ${ }^{34}$

\section{$A L K$ and $p A L K$ Expression in the Spectrum of $N B L, G N B L$, and GN}

To examine ALK expression in NBL, GNBL, and GN, we estimated ALK and pALK levels by IHC staining in tumor sections. The results for PALK staining were not evaluable because both pALK Y1604 antibodies produced nonspecific staining (results not shown). By using total ALK antibodies, predominantly membranous and often cytoplasmic ALK staining was observed in tumor cells of most of the NBL and GNBL samples (Figure 1A). GN samples showed limited staining of ALK, and almost exclusively cytoplasmic staining in $5 \%$ to $80 \%$ of ganglion cells was observed (Figure 1B). NBLs and GNBLs are intrinsically immature tumors but can exhibit variable degrees of differentiation. Figure $1 \mathrm{C}$ represents an example of an NBL with intensive neuroblast staining and a transition zone with fewer tumor cells and concomitant decrease in ALK staining, toward staining of selective ganglion cells in the most differentiated part of the tumor biopsy specimen. To exclude effects of antigen retrieval on IHC result, we performed ALK IHC in four matched frozen sections of patients in our cohort. Results from FFPE and frozen samples were largely comparable, and did not show different staining patterns.

In addition, we noticed that the degree of ALK staining varied among patient samples. To establish the degree of ALK positivity in each tumor, percentages of ALK-positive cells were divided in four categories, as described in 


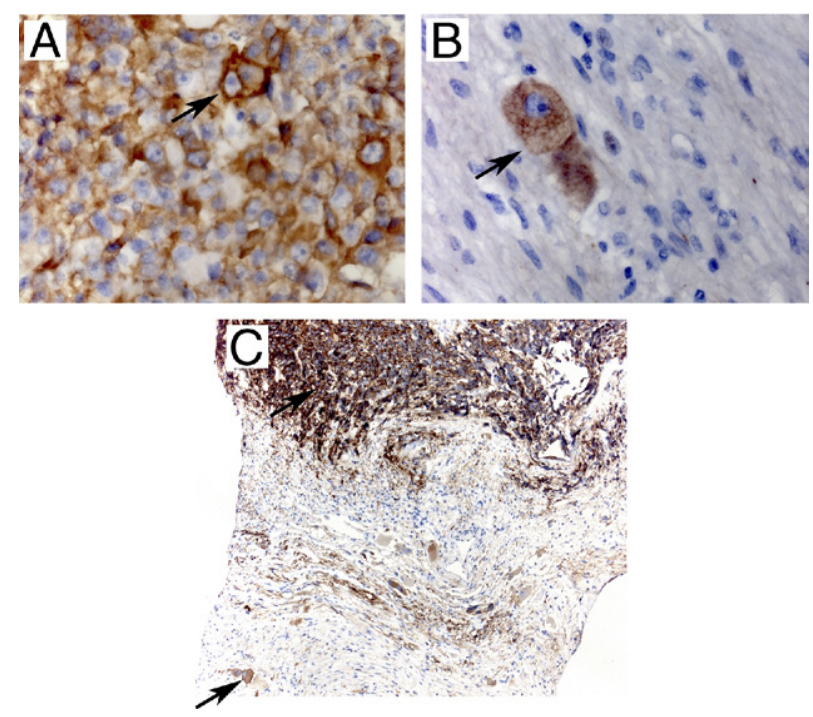

Figure 1. ALK IHC staining patterns in different tumor types. A: A representative NBL sample that demonstrates predominant membrane staining (arrow) of ALK in neuroblasts (IHC). Original magnification, $\times 63$. B: A representative GN sample with cytoplasmic staining (arrow) of only ganglion cells (IHC). Original magnification, $\times 63$. C: NBL needle biopsy specimen with strong staining of the neuroblastic component (upper arrow), a transition zone with less intensive staining and ganglion cell staining in the matured bottom part of the sample (lower arrow) (IHC). Original magnification, $\times 10$.

Materials and Methods. Several statistically significant associations between ALK IHC staining categories and patient or tumor characteristics were identified. First, an increase in the number of cells that stained positive for ALK was observed between histological subgroups. Of the GNs, 90\% have the lowest levels of ALK positivity and were assigned to category 1. Nearly half of the GNBLs had more ALK-positive cells and were categorized in category 2 to 4 . NBLs were mostly positive for ALK, and approximately $50 \%$ of tumor samples from patients with NBL contained many ALK-positive cells (category 3 or 4 ) $(P<0.001$; Table 3 and Figure 2A). Second, the association between increasing ALK staining and decreasing degree of differentiation was further shown by the correlation with the International Neuroblastoma Pathology Committee classification $(P<0.001$; see Supplemental Figure S1 at http://ajp.amjpathol.org). Furthermore, a strong trend was observed for increased ALK levels and advanced INSS staging (Table 3; $P=0.08$ ). Higher ALK levels were significantly correlated with advanced INSS stage IV NBL disease (Figure 2B; $P=0.018$ ). The median ages for patients who were included in different ALK categories were different $(P=0.031)$, although no relationship was identified with ALK positivity levels (Table 3; $P=0.058$ ). For COG risk classification and MYCN status, no relation was observed with ALK positivity levels (Table 3). ${ }^{33}$

\section{ALK Mutation Analyses}

We then investigated $A L K$ mutation status of NBL, GNBL, and GN patient samples, and tested whether this was associated with increased ALK levels. For this, DNA isolated from tissue sections that contain $>70 \%$ of tumor cells (93 of the 103 samples) and good DNA quality (90 of the 93 samples) was screened for mutations in the kinase domain of ALK (exons 20 and 22 to 25). We found two mutations in $62 \mathrm{NBL}$ patient samples (3.2\%; F1245I

Table 3. Patient Characteristics for ALK Positivity Categories

\begin{tabular}{|c|c|c|c|c|c|c|}
\hline Characteristics & ALK 1 & ALK 2 & ALK 3 & ALK 4 & $P$ value & $\begin{array}{l}P \text { value for } \\
\text { trend }\end{array}$ \\
\hline Patients [no. (\%)] & $42(41)$ & $22(21)$ & $25(24)$ & $14(14)$ & & \\
\hline Median age at diagnosis (years) & 3.7 & 1.3 & 2.7 & 2.3 & $0.031^{*}$ & $0.058^{+}$ \\
\hline Male/female ratio & 0.57 & 0.73 & 0.44 & 0.57 & $0.267^{\ddagger}$ & $0.547^{\S}$ \\
\hline Histological features [no. (\%)] & & & & & & $<0.001^{\text {ๆ }}$ \\
\hline Ganglioneuroma & $18(90)$ & $1(5)$ & $0(0)$ & $1(5)$ & $<0.001^{\ddagger}$ & \\
\hline Ganglioneuroblastoma & $7(58)$ & $1(8)$ & $3(25)$ & $1(8)$ & $0.496^{\ddagger}$ & \\
\hline Neuroblastoma & $17(24)$ & $20(28)$ & $22(31)$ & $12(17)$ & $<0.001^{\ddagger}$ & \\
\hline INSS stage for GNBL and NBL [no. (\%)] & & & & & & $<0.080^{\text {ๆ** }}$ \\
\hline l & $2(20)$ & $5(50)$ & $2(20)$ & $1(10)$ & $0.299^{\ddagger}$ & \\
\hline II & $4(40)$ & $1(10)$ & $3(30)$ & $2(20)$ & $0.612^{\ddagger}$ & \\
\hline III & $7(47)$ & $4(27)$ & $4(27)$ & $0(0)$ & $0.176^{\ddagger}$ & \\
\hline IV & $10(22)$ & $9(20)$ & $16(36)$ & $10(22)$ & $0.099^{\ddagger}$ & \\
\hline IVs & $1(33)$ & $2(67)$ & $0(0)$ & $0(0)$ & $0.314^{\ddagger}$ & \\
\hline Risk group (COG): risk stratification possible & $24(30)$ & $18(23)$ & $24(30)$ & $13(16)$ & & $<0.469^{\Uparrow}$ \\
\hline Low & 7 (33) & $6(29)$ & $5(24)$ & $3(14)$ & $0.803^{\ddagger}$ & \\
\hline Medium & $4(25)$ & $5(31)$ & $5(31)$ & $2(13)$ & $<0.797^{\ddagger}$ & \\
\hline High & $13(31)$ & $7(17)$ & $14(33)$ & $8(19)$ & $<0.551^{\ddagger}$ & \\
\hline ALK mutation present/tested & $0 / 35$ & $0 / 20$ & $2 / 23$ & $2 / 12$ & $0.051^{\ddagger}$ & $0.010^{\S}$ \\
\hline MYCN status present/tested & $2 / 25$ & $2 / 14$ & $2 / 19$ & $2 / 13$ & $0.891^{\ddagger}$ & $0.564^{\S}$ \\
\hline
\end{tabular}

Characteristics of patients with different percentages of ALK-positive cells in tumor biopsy specimens (categories 1 to 4 ) are shown in horizontal direction. $P$ values discriminating the different ALK categories are calculated. Significant $P$ values $(P<0.05)$ are boldfaced. INSS stage, COG risk group, and MYCN status was only determined for GNBL and NBL.

${ }^{*}$ Kruskal-Wallis test.

†Jonckheere-Terpstra test.

${ }^{\ddagger} \chi^{2}$ Test.

$\$ \chi^{2}$ Test for trend.

"Spearman's rank correlation coefficient.

**Exclusion of INSS stage IVs from trend analysis. 

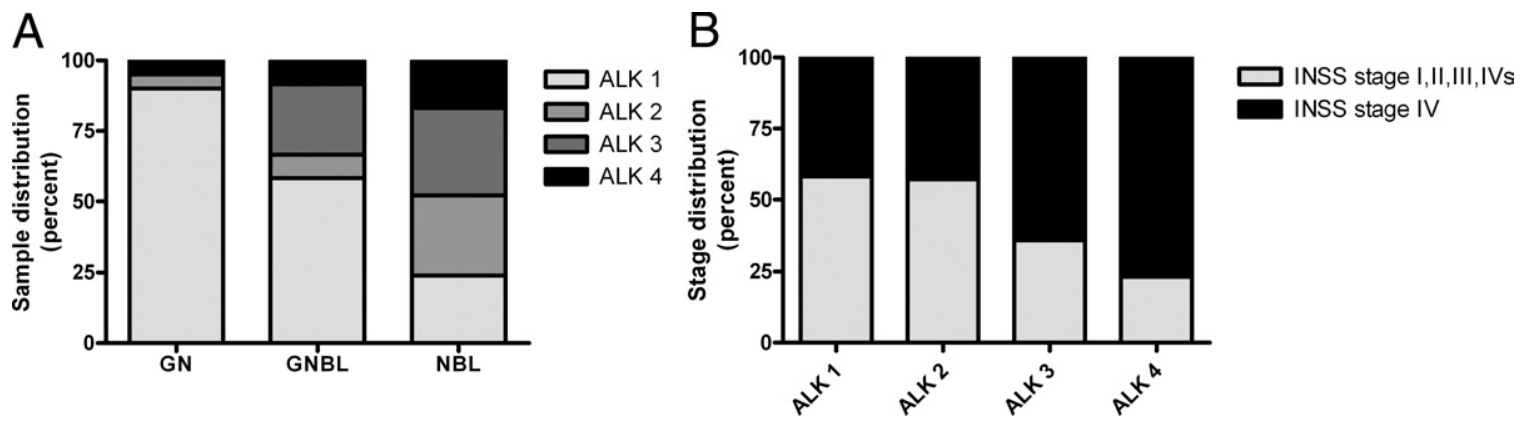

Figure 2. High ALK positivity coincides with tumor subtype and high INSS stage. A: The degree of ALK staining is higher in NBL versus GNBL versus GN. $P<$ 0.001 (Spearman's rank correlation coefficient). B: The proportion of INSS stage IV disease increases with enhanced ALK positivity levels. $P=0.018$ ( $\chi^{2}$ test for trend).

and $\mathrm{R} 1275 \mathrm{Q})$ and two mutations in 11 GNBL patient samples (18.2\%; F1174L and R1275Q). No mutations were identified in any of our $17 \mathrm{GN}$ tissue samples. Identical ALK mutations have been previously described. ${ }^{7-11}$ All four ALK mutant patient samples had many ALKpositive cells, and were categorized in category 3 or 4 $(P=0.011)$. Whether $A L K$ mutations are necessarily associated with many ALK-positive cells is difficult to assess because overall numbers of mutant $A L K$ patient biopsy specimens were low in our study. Mutant ALK may also be associated with poor patient outcome because two of the four patients with an ALK-mutated tumor died; however, again, the few mutated cases do not allow for a reliable statistical analysis on survival.

\section{Prognostic Significance of ALK Positivity}

The positive relationship between the number of cells that were positive for ALK and high clinical stage prompted us to further investigate the correlation of ALK tumor positivity and patient survival. Increasing ALK levels, as categorized, were negatively correlated with overall survival for the combined NBL, GNBL, and GN patient group (Figure $3 \mathrm{~A} ; P=0.002$ ). Because patients with $\mathrm{GN}$ have an excellent outcome ${ }^{34}$ and their tumor samples contain few positive cells, ALK tumor positivity levels may not be related to outcome in these patients. After exclusion of these patients with GN from our analysis, a strong significant trend was observed again between higher ALK tumor positivity levels and poor outcome in patients with NBL and GNBL (Figure 3B; $P=0.020$ ).

Consequently, a multivariate Cox proportional hazard analysis was performed that included the COG risk stratification (based on MYCN status, INSS stage, age, ploidy, and histological features) ${ }^{33}$ and our new classification for ALK positivity levels in tumor biopsy specimens (categories 1 to 4) (Table 4). When performed in patients with GNBL and NBL $(n=83)$, ALK positivity levels were demonstrated as an independent prognostic factor, with an increasing hazard ratio of $1.7,3.4$, and 3.6 for each consecutive category (categories 2 to 4 , respectively). The current COG risk stratification remained the strongest prognostic factor for predicting NBL and GNBL patient survival, with a hazard ratio of $41.7(P<0.001)$.

\section{Discussion}

In this study, high numbers of ALK-positive cells in tumor samples were correlated with an inferior prognosis in patients with NBL and GNBL. High content of ALK-posi-
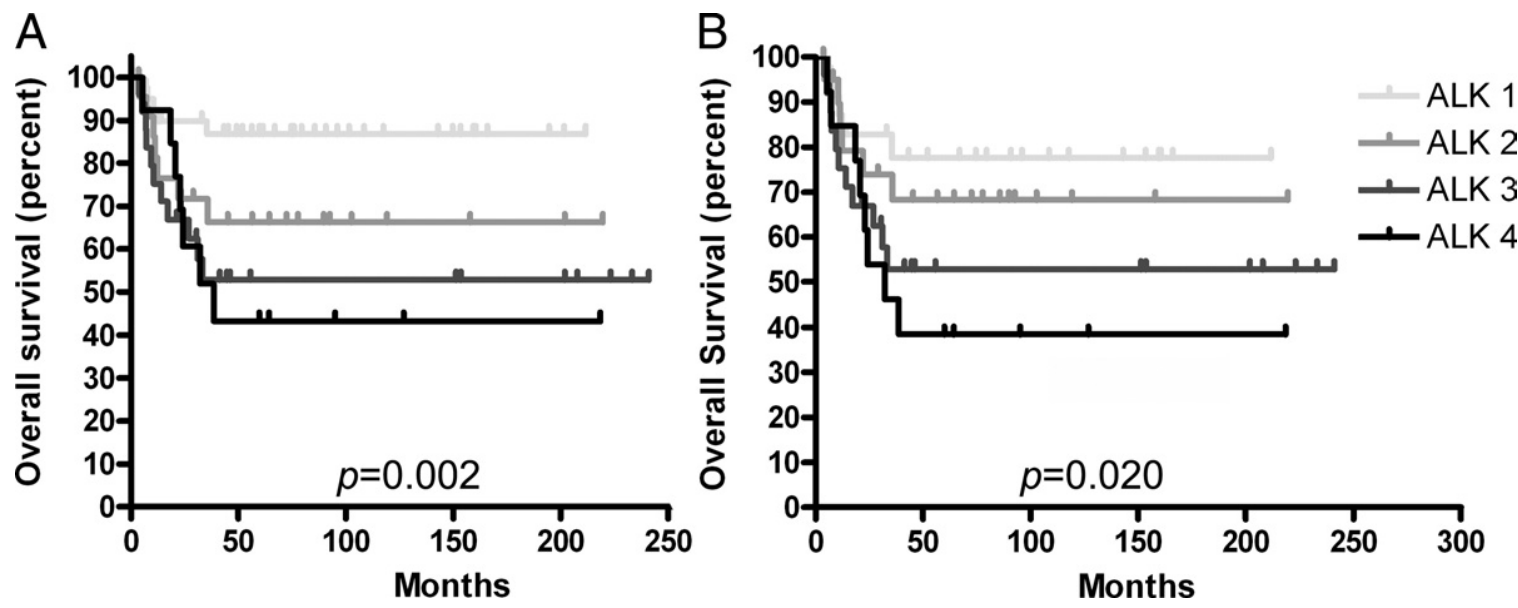

Figure 3. Higher ALK positivity correlates with inferior overall survival. A: Increasing ALK positivity is correlated with decreased overall survival in the group of patients with NBL, GNBL, and GN. $P=0.002$. B: Increasing ALK positivity remains significantly correlated with decreased overall survival in patients with NBL and GNBL. $P=0.020$. 
Table 4. Multivariate Analysis of ALK Positivity Categories

\begin{tabular}{lccr}
\hline \multicolumn{1}{c}{ Category } & $\begin{array}{c}\text { Hazard } \\
\text { ratio }\end{array}$ & \multicolumn{1}{c}{$95 \% \mathrm{Cl}$} & $P$ value \\
\hline ALK 1 & 1 & $\mathrm{NA}$ & 0.087 \\
ALK 2 & 1.745 & $0.504-6.038$ & 0.379 \\
ALK 3 & 3.367 & $1.157-9.800$ & 0.026 \\
ALK 4 & 3.564 & $1.146-11.088$ & 0.028 \\
COG classification & 41.717 & $5.637-308.713$ & $<0.001$ \\
\hline
\end{tabular}

Results of a Cox proportional hazard model including the COG risk classification and categories with percentages of ALK-positive staining cells. For the COG classification, high-risk group patients were compared with low- and intermediate-risk group patients. Low- and intermediate-risk patients were grouped together because no event was present in the low-risk group. Adding ALK mutation status to this model did not give a significant result, although only four patients carried a mutation. Significant $P$ values $(P<0.05)$ are boldfaced.

$\mathrm{NA}$, not available.

tive cells in tumors was also related to advanced tumor types (NBL versus GN) and high INSS stage (stage IV versus stages I to III), but, surprisingly, was not related to COG risk stratification. Furthermore, multivariate analysis indicates that high ALK tumor positivity level and COG risk stratification are independent poor prognostic factors for patients with NBL and GNBL. We also studied the relationship between ALK mutations and the number of ALKpositive cells in tumor samples, and all ALK mutant samples comprised high percentages of ALK-positive cells. ALK mutations were identified in $18.2 \%$ of GNBL patient samples and, to the best of our knowledge, have not been previously described. The influence of ALK mutation status in relation to outcome for patients with NBL and GNBL could not be established because of the few patients with an ALK mutation.

ALK tumor positivity did not correlate with the current COG risk classification, although it did correlate with INSS stage and degree of differentiation, which are part of the COG risk classifier. First, the absence of this correlation is most likely caused by the large influence of MYCN status on the COG risk stratification. Second, age did not correlate with ALK status either, although this also has a large influence in determining COG risk groups. The strong correlation between tumor differentiation, determined by International Neuroblastoma Pathology Committee classification, and ALK staining is interesting. ALK plays a role in early sympathetic nerve cell development and proliferation. ${ }^{35}$ Lower ALK levels in more differentiated tumors might indicate a decrease of ALK in sympathetic neuron development or lineage diversification.

For patients with GN and GNBL, we observed that many ganglion cells in tumor biopsy specimens are positive for ALK. One hypothesis is that these cells have evolved from malignant neuroblasts. In this respect, it would be interesting to establish whether cells in normal fetal or adult adrenal glands stain positive for ALK. The absence of staining of these cells would be in favor of the previous hypothesis. In the case of positive staining, this would imply that ALK is important for early development of neural crest cells and is involved in the late differentiation or maintenance of neuroendocrine cells. More research toward the identification of the function of ALK in neuronal differentiation might clarify the ALK positivity in differentiated neuronal cell types, such as ganglion cells. We also observed that the cellular ALK staining pattern of ganglion cells is different compared with neuroblast cells. ALK in ganglion cells is predominantly found in the cytoplasm, whereas the ALK staining pattern in neuroblast cells is predominantly found at the membranous structures in these cells and in the cytoplasm. Recently, Mazot et $\mathrm{al}^{36}$ published that $A L K$ mutated cell lines predominantly have intracellular ALK staining because of a defective $\mathrm{N}$-glycosylation that retains the mutant ALK proteins in the endoplasmic reticulum or Golgi apparatus. This defect could, at least in part, be resolved by kinase inhibition, which resulted in mobilization of mutant ALK to the membrane. We hypothesize that this mechanism is endogenous for wild-type ALK proteins and may explain predominant ALK cytoplasmic staining in ALK wild-type tumor biopsy specimens.

High ALK protein expression in NBL samples has been associated with inferior prognosis in univariate analyses. ${ }^{13,22}$ Both studies compared NBL patient survival with the percentage of ALK-positive tumor cells using IHC. These studies distinguished tumor biopsy specimens with $>50 \%$ of ALK-positive cells from tumor biopsy specimens with $<50 \%{ }^{13,22}$ or $<10 \%{ }^{13,22}$ of ALK-positive cells. Because the number of ALK-positive cells in tumor samples ranged from $0 \%$ to $100 \%$, we distinguished four categories with increasing percentages of ALK-positive cells, each comprising a comparable number of patient samples and comparable with categories in previous publications. ${ }^{13,22}$ In line with both previous studies, ${ }^{13,22}$ we observed a significant correlation with poor outcome for samples that comprised $>50 \%$ of ALK-positive cells. This correlation with poor outcome remained significant in multivariate analysis. Because each consecutive category with increasing numbers of ALK-positive cells had a stronger predictive value toward poor outcome, we believe that our stratification method has additional prognostic relevance and should be further tested in a prospective study.

In a previous cell line study, ${ }^{31}$ we showed that the cellular response to ALK inhibitors is correlated with ALK mRNA and protein levels. All four samples with an $A L K$ mutation in this study had high levels of ALK, in accordance with previous reports, ${ }^{13,22}$ and these patients may benefit from ALK inhibitor treatment, as shown for NBL cell lines. ${ }^{9,13,26,36}$ In this respect, clinical phase 1, 2, and 3 trials with the ALK inhibitor PF2341066 (Pfizer) are being conducted in pediatric and adult patients with solid tumors comprising ALK aberrations. ${ }^{37-43}$ We suggest that ALK positivity in the absence of $A L K$ mutations may also predict response toward ALK inhibitors. This has also been suggested in other studies, ${ }^{13,22}$ and ALK might play a role in the pathogenesis of this disease despite the absence of $A L K$ mutations in most NBL or GNBL patient samples. In these cases, an autocrine or paracrine mechanism can explain ALK activation. ${ }^{35}$

The oncogenic effect of ALK mutant molecules (F1174L and K1062M) has been demonstrated in mice. ${ }^{8}$ It remains to be established whether high levels of ALK itself may behave oncogenically in mice. There are 
various arguments that this may be the case. First, high ALK tumor positivity is correlated with poor outcome (in this and other studies). ${ }^{13,22}$ Second, in immature sympathetic neurons, high wild-type and mutant ALK both stimulated proliferation. ${ }^{35}$ Third, high ALK expression correlated with PHOX2B expression in NBL cell lines. ${ }^{31,44}$ PHOX2B is mutated in a few patients with $\mathrm{NBL}^{45}$ and is an important regulator of neural crest differentiation. ${ }^{44}$ Last, researchers ${ }^{10,31}$ have also shown that NBL cell lines with high ALK expression, in the absence of ALK mutations, are sensitive to ALK inhibitor treatment.

In conclusion, ALK tumor positivity is an independent poor prognostic marker for patients with NBL and GNBL.

\section{Acknowledgments}

We thank Bram van Gessel for help in cutting the FFPE material and Esther Korpershoek for help in sequencing the ALK gene.

\section{References}

1. Deyell RJ, Attiyeh EF: Advances in the understanding of constitutional and somatic genomic alterations in neuroblastoma. Cancer Genet 2011, 204:113-121

2. Michels E, Vandesompele J, De Preter K, Hoebeeck J, Vermeulen J, Schramm A, Molenaar JJ, Menten B, Marques B, Stallings RL, Combaret V, Devalck C, De Paepe A, Versteeg R, Eggert A, Laureys G, Van Roy N, Speleman F: ArrayCGH-based classification of neuroblastoma into genomic subgroups. Genes Chromosomes Cancer 2007, 46:1098-1108

3. Brodeur GM: Neuroblastoma: biological insights into a clinical enigma. Nat Rev Cancer 2003, 3:203-216

4. Maris JM: The biologic basis for neuroblastoma heterogeneity and risk stratification. Curr Opin Pediatr 2005, 17:7-13

5. Brodeur GM, Seeger RC, Schwab M, Varmus HE, Bishop JM: Amplification of $\mathrm{N}$-myc in untreated human neuroblastomas correlates with advanced disease stage. Science 1984, 224:1121-1124

6. Molenaar JJ, van Sluis P, Boon K, Versteeg R, Caron HN: Rearrangements and increased expression of cyclin D1 (CCND1) in neuroblastoma. Genes Chromosomes Cancer 2003, 36:242-249

7. Caren $\mathrm{H}$, Abel F, Kogner $\mathrm{P}$, Martinsson T: High incidence of DNA mutations and gene amplifications of the ALK gene in advanced sporadic neuroblastoma tumours. Biochem J 2008, 416:153-159

8. Chen Y, Takita J, Choi YL, Kato M, Ohira M, Sanada M, Wang L, Soda M, Kikuchi A, Igarashi T, Nakagawara A, Hayashi Y, Mano H, Ogawa $\mathrm{S}$ : Oncogenic mutations of ALK kinase in neuroblastoma. Nature 2008, 455:971-974

9. George RE, Sanda T, Hanna M, Frohling S, Luther W 2nd, Zhang J, Ahn Y, Zhou W, London WB, McGrady P, Xue L, Zozulya S, Gregor VE, Webb TR, Gray NS, Gilliland DG, Diller L, Greulich H, Morris SW, Meyerson M, Look AT: Activating mutations in ALK provide a therapeutic target in neuroblastoma. Nature 2008, 455:975-978

10. Janoueix-Lerosey I, Lequin D, Brugieres L, Ribeiro A, de Pontual L, Combaret V, Raynal V. Puisieux A, Schleiermacher G, Pierron G, Valteau-Couanet D, Frebourg T, Michon J, Lyonnet S, Amiel J, Delattre O: Somatic and germline activating mutations of the ALK kinase receptor in neuroblastoma. Nature 2008, 455:967-970

11. Mosse YP, Laudenslager M, Longo L, Cole KA, Wood A, Attiyeh EF, Laquaglia MJ, Sennett R, Lynch JE, Perri P, Laureys G, Speleman F, Kim C, Hou C, Hakonarson H, Torkamani A, Schork NJ, Brodeur GM, Tonini GP, Rappaport E, Devoto M, Maris JM: Identification of ALK as a major familial neuroblastoma predisposition gene. Nature 2008, 455:930-935

12. Osajima-Hakomori Y, Miyake I, Ohira M, Nakagawara A, Nakagawa A, Sakai R: Biological role of anaplastic lymphoma kinase in neuroblastoma. Am J Pathol 2005, 167:213-222
13. Passoni L, Longo L, Collini P, Coluccia AM, Bozzi F, Podda M, Gregorio A, Gambini C, Garaventa A, Pistoia V, Del Grosso F, Tonini GP, Cheng M, Gambacorti-Passerini C, Anichini A, Fossati-Bellani F, Di Nicola M, Luksch R: Mutation-independent anaplastic lymphoma kinase overexpression in poor prognosis neuroblastoma patients. Cancer Res 2009, 69:7338-7346

14. Motegi A, Fujimoto J, Kotani M, Sakuraba H, Yamamoto T: ALK receptor tyrosine kinase promotes cell growth and neurite outgrowth. J Cell Sci 2004, 117:3319-3329

15. Schonherr C, Yang HL, Vigny M, Palmer RH, Hallberg B: Anaplastic lymphoma kinase activates the small GTPase Rap1 via the Rap1specific GEF C3G in both neuroblastoma and PC12 cells. Oncogene 2010, 29:2817-2830

16. Iwahara T, Fujimoto J, Wen D, Cupples R, Bucay N, Arakawa T, Mori $\mathrm{S}$, Ratzkin B, Yamamoto T: Molecular characterization of ALK, a receptor tyrosine kinase expressed specifically in the nervous system. Oncogene 1997, 14:439-449

17. Degoutin J, Brunet-de Carvalho N, Cifuentes-Diaz C, Vigny M: ALK (anaplastic lymphoma kinase) expression in DRG neurons and its involvement in neuron-Schwann cells interaction. Eur $\mathrm{J}$ Neurosc 2009, 29:275-286

18. Morris SW, Naeve C, Mathew P, James PL, Kirstein MN, Cui X, Witte DP: ALK, the chromosome 2 gene locus altered by the $t(2 ; 5)$ in non-Hodgkin's lymphoma, encodes a novel neural receptor tyrosine kinase that is highly related to leukocyte tyrosine kinase (LTK). Oncogene 1997, 14:2175-2188

19. Vernersson E, Khoo NK, Henriksson ML, Roos G, Palmer RH, Hallberg B: Characterization of the expression of the ALK receptor tyrosine kinase in mice. Gene Expr Patterns 2006, 6:448-461

20. Li R, Morris SW: Development of anaplastic lymphoma kinase (ALK) small-molecule inhibitors for cancer therapy. Med Res Rev 2008, 28:372-412

21. Pulford K, Lamant L, Morris SW, Butler LH, Wood KM, Stroud D, Delsol G, Mason DY: Detection of anaplastic lymphoma kinase (ALK) and nucleolar protein nucleophosmin (NPM)-ALK proteins in norma and neoplastic cells with the monoclonal antibody ALK1. Blood 1997 89:1394-1404

22. De Brouwer S, De Preter K, Kumps C, Zabrocki P, Porcu M, Westerhout EM, Lakeman A, Vandesompele J, Hoebeeck J, Van Maerken T, De Paepe A, Laureys G, Schulte JH, Schramm A, Van Den Broecke C, Vermeulen J, Van Roy N, Beiske K, Renard M, Noguera R, Delattre O, Janoueix-Lerosey I, Kogner P, Martinsson T, Nakagawara A, Ohira M, Caron H, Eggert A, Cools J, Versteeg R, Speleman F: Metaanalysis of neuroblastomas reveals a skewed ALK mutation spectrum in tumors with MYCN amplification. Clin Cancer Res 2010, 16:43534362

23. Lamant L, Pulford K, Bischof D, Morris SW, Mason DY, Delsol G, Mariame B: Expression of the ALK tyrosine kinase gene in neuroblastoma. Am J Pathol 2000, 156:1711-1721

24. Willoughby V, Sonawala A, Werlang-Perurena A, Donner LR: A comparative immunohistochemical analysis of small round cell tumors of childhood: utility of peripherin and alpha-internexin as markers for neuroblastomas. Appl Immunohistochem Mol Morphol 2008, 16:344348

25. Schulte JH, Bachmann HS, Brockmeyer B, Depreter K, Oberthür A, Ackermann S, Kahlert Y, Pajtler K, Theissen J, Westermann F, Vandesompele J, Speleman F, Berthold F, Eggert A, Brors B, Hero B, Schramm A, Fischer M: High ALK receptor tyrosine kinase expression supersedes ALK mutation as a determining factor of an unfavorable phenotype in primary neuroblastoma. Clin Cancer Res 2011, 17: $5082-5092$

26. Stock C, Bozsaky E, Watzinger F, Poetschger U, Orel L, Lion T, Kowalska A, Ambros PF: Genes proximal and distal to MYCN are highly expressed in human neuroblastoma as visualized by comparative expressed sequence hybridization. Am J Pathol 2008, 172:203214

27. McDermott U, lafrate AJ, Gray NS, Shioda T, Classon M, Maheswaran S, Zhou W, Choi HG, Smith SL, Dowell L, Ulkus LE, Kuhlmann G, Greninger P, Christensen JG, Haber DA, Settleman J: Genomic alterations of anaplastic lymphoma kinase may sensitize tumors to anaplastic lymphoma kinase inhibitors. Cancer Res 2008, 68:3389_ 3395

28. Umehara S, Nakagawa A, Matthay KK, Lukens JN, Seeger RC, Stram DO, Gerbing RB, Shimada H: Histopathology defines prognostic 
subsets of ganglioneuroblastoma, nodular. Cancer 2000, 89: 1150-1161

29. Peuchmaur M, d'Amore ES, Joshi VV, Hata J, Roald B, Dehner LP, Gerbing RB, Stram DO, Lukens JN, Matthay KK, Shimada H: Revision of the International Neuroblastoma Pathology Classification: confirmation of favorable and unfavorable prognostic subsets in ganglioneuroblastoma, nodular. Cancer 2003, 98:2274-2281

30. Caron $\mathrm{H}$, van Sluis $\mathrm{P}$, van Hoeve M, de Kraker J, Bras J, Slater R, Mannens M, Voute PA, Westerveld A, Versteeg R: Allelic loss of chromosome 1 p36 in neuroblastoma is of preferential maternal origin and correlates with N-myc amplification. Nat Genet 1993, 4:187-190

31. Duijkers FA, Gaal J, Meijerink JP, Admiraal P, Pieters R, de Krijger RR, van Noesel MM: Anaplastic lymphoma kinase (ALK) inhibitor response in neuroblastoma is highly correlated with ALK mutation status, ALK mRNA and protein levels. Cell Oncol (Dordr) 2011, 34 409-417

32. Haupt R, Garaventa A, Gambini C, Parodi S, Cangemi G, Casale F, Viscardi E, Bianchi M, Prete A, Jenkner A, Luksch R, Di Cataldo A, Favre C, D'Angelo P, Zanazzo GA, Arcamone G, Izzi GC, Gigliotti AR, Pastore G, De Bernardi B: Improved survival of children with neuroblastoma between 1979 and 2005: a report of the Italian Neuroblastoma Registry. J Clin Oncol 2010, 28:2331-2338

33. Park JR, Eggert A, Caron H: Neuroblastoma: biology, prognosis, and treatment. Hematol Oncol Clin North Am 2010, 24:65-86

34. Okamatsu C, London WB, Naranjo A, Hogarty MD, Gastier-Foster JM, Look AT, LaQuaglia M, Maris JM, Cohn SL, Matthay KK, Seeger RC, Saji T, Shimada H: Clinicopathological characteristics of ganglioneuroma and ganglioneuroblastoma: a report from the CCG and COG. Pediatr Blood Cancer 2009, 53:563-569

35. Reiff T, Huber L, Kramer M, Delattre O, Janoueix-Lerosey I, Rohrer H: Midkine and Alk signaling in sympathetic neuron proliferation and neuroblastoma predisposition. Development 2011, 138:4699-4708

36. Mazot P, Cazes A, Boutterin MC, Figueiredo A, Raynal V, Combaret V, Hallberg B, Palmer RH, Delattre O, Janoueix-Lerosey I, Vigny M: The constitutive activity of the ALK mutated at positions F1174 or R1275 impairs receptor trafficking. Oncogene 2011, 30:2017-2025

37. Garber K: ALK, lung cancer, and personalized therapy: portent of the future? J Natl Cancer Inst 2010, 102:672-675

38. Mosse YP, Wood A, Maris JM: Inhibition of ALK signaling for cancer therapy. Clin Cancer Res 2009, 15:5609-5614

39. Webb TR, Slavish J, George RE, Look AT, Xue L, Jiang Q, Cui X, Rentrop WB, Morris SW: Anaplastic lymphoma kinase: role in cancer pathogenesis and small-molecule inhibitor development for therapy. Expert Rev Anticancer Ther 2009, 9:331-356

40. Ardini E, Magnaghi P, Orsini P, Galvani A, Menichincheri M: Anaplastic lymphoma kinase: role in specific tumours, and development of small molecule inhibitors for cancer therapy. Cancer Lett 2010, 299: 81-94

41. Martinsson $T$, Eriksson $T$, Abrahamsson J, Caren $H$, Hansson $M$, Kogner P, Kamaraj S, Schonherr C, Weinmar J, Ruuth K, Palmer RH, Hallberg B: Appearance of the novel activating F1174S ALK mutation in neuroblastoma correlates with aggressive tumor progression and unresponsiveness to therapy. Cancer Res 2011, 71:98-105

42. Milkiewicz KL, Ott GR: Inhibitors of anaplastic lymphoma kinase: a patent review. Expert Opin Ther Pat 2010, 20:1653-1681

43. Kelleher FC, McDermott R: The emerging pathogenic and therapeutic importance of the anaplastic lymphoma kinase gene. Eur $\mathrm{J}$ Cancer 2010, 46:2357-2368

44. Bachetti T, Di Paolo D, Di Lascio S, Mirisola V, Brignole C, Bellotti M, Caffa I, Ferraris C, Fiore M, Fornasari D, Chiarle R, Borghini S, Pfeffer U, Ponzoni M, Ceccherini I, Perri P: PHOX2B-mediated regulation of ALK expression: in vitro identification of a functional relationship between two genes involved in neuroblastoma. PLoS One 2010, 5:e13108

45. Raabe EH, Laudenslager M, Winter C, Wasserman N, Cole K, LaQuaglia M, Maris DJ, Mosse YP, Maris JM: Prevalence and functional consequence of $\mathrm{PHOX} 2 \mathrm{~B}$ mutations in neuroblastoma. Oncogene 2008, 27:469-476 